\title{
The Tourist Hotel Corporation: It is time the story was told in full
}

\section{David Williamson}

David is Senior Lecturer at the School of

Hospitality and

Tourism, Auckland

University of

Technology. He spent 18 years working in the hospitality industry as a hotel manager and restaurateur. His research includes work, employment and labour market issues in hospitality and tourism. David completed his PhD in 2017 - a history of employment relations in the New Zealand hotel sector, 1955-2000.

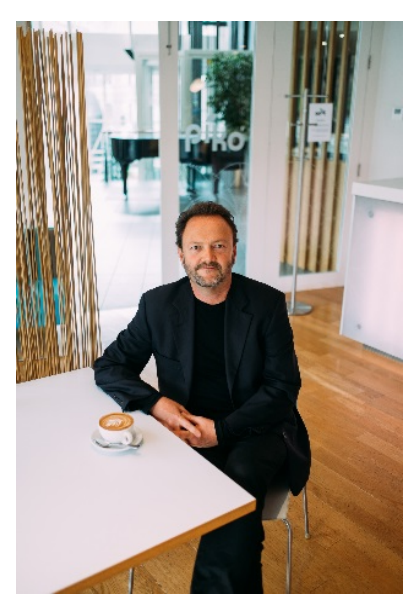

\author{
Ki te kore nga putake e mākukungia e kore te rakau e tupu \\ If the roots of the tree are not watered the tree will never grow
}

New Zealand is in the middle of the most dramatic and sustained boom in tourism and hospitality in its history. The hotel sector that underpins our tourism growth stands utterly transformed from its humble beginnings. Yet the history of the Tourist Hotel Corporation (THC) and its role as the 'roots' of the modern hotel industry still tends to be told only as a minor part of our wider tourism story. Recent PhD research [1], based on extensive archive sources and interviews with senior practitioners, argues that the time has come for the THC story to be told in full.

While there have been histories of the tourism and hospitality sector that cover the THC [2-7], they have not included in-depth discussion of the origins, structure and legacies of the organisation. Established in 1955 and sold in 1991, the THC dominated the New Zealand tourist hotel sector for 35 years, running around 10 resort-style properties and setting the standard for service. However, the current dominance of neo-liberal ideology has resulted in the achievements of the Government-owned THC being somewhat dismissed and the role of massive Government investment in the development of our hotel sector often being 'conveniently' forgotten. It is common for the THC to be depicted as rather archaic. Burdened with political interference and gross underfunding, the THC is sometimes depicted as a prime example of what happens when the state tries to run a business.

However, this research argues there is a more heroic telling of the THC story, one that celebrates the THC as the fundamental 'roots' of the modern hotel sector. The THC was a key player in transforming post-war New Zealand hospitality, raising the bar for service, food and beverage and accommodation significantly. The THC invested heavily in improving buildings, vehicles, equipment and machinery, developing the skills and careers of its staff, and innovating menus. Staff from the THC were seen as 'A grade' and many of today's most successful General Managers learnt their trade in THC properties. Many THC staff also went on to set up influential restaurants outside of hotels during this period.

The THC managed significant tourism development even while showing a profit from 1974 till the late 1980s, posting a 2.7 million dollar surplus in 1986. However, a combination of perceived indebtedness, the 1987 recession and free-market Government ideology resulted in the sale of the THC to the Southern Pacific Hotel Corporation in 1991. The story of the THC involves drama, intrigue, politics, high finance, rapid growth and equally rapid collapse. But most importantly, this is the story of the origins of our hotel industry, showing the huge contribution this state 
funded group made to the modern industry. Surely it is time this story was told in full, on its own terms and in glorious technicolour.

If you would like to read the $\mathrm{PhD}$ thesis this research is based on you can access it here: https://aut.researchgateway.ac.nz/handle/10292/10412

\section{Corresponding author}

David Williamson can be contacted at: david.williamson@aut.ac.nz

\section{References}

(1) Williamson, D. In Search of Consensus: A History of Employment Relations in the New Zealand Hotel Sector - 1955 to 2000; Ph.D. Thesis, Auckland University of Technology, 2017.

(2) Brien, A. 100 Years of Hospitality in New Zealand: The People, the Politics, the Passion; Wellington Museums Trust in association with the Hospitality Association of NZ: Wellington, New Zealand, 2003.

(3) McClure, M. The Wonder Country: Making New Zealand Tourism; Auckland University Press: Auckland, New Zealand, 2004.

(4) Medlik, S. The Business of Hotels, 4th ed.; Butterworth-Heinemann: Oxford, U.K., 2000.

(5) Slattery, P. The Economic Ascent of the Hotel Business; Goodfellow Publishers: Oxford, U.K., 2009.

(6) Watkins, L. Billion Dollar Miracle: The Authentic Story of the Birth and Amazing Growth of the Tourism Industry in New Zealand; Travel Agents Association of New Zealand: Auckland, New Zealand, 1987.

(7) Yu, L. The International Hospitality Business: Management and Operations; Haworth Press: New York, 1999. 